\author{
Magdalena Pochwała* \\ ORCID: 0000-0001-5902-3862 \\ Uniwersytet Wrocławski, Wydział Prawa, Administracji i Ekonomii
}

DOI: $10.19195 / 1733-5779.27 .3$

\title{
Prozdrowotny styl życia polskich studentów
}

\section{JEL Classification: I12}

Słowa kluczowe: styl życia, prozdrowotny styl życia, zdrowie

Keywords: lifestyle, healthy lifestyle, health

\begin{abstract}
Abstrakt: Celem artykułu jest identyfikacja czynników wpływających na stan zdrowia polskich studentów. Artykuł powstał na podstawie przeglądu literatury oraz badań ilościowych przeprowadzonych w kwietniu i maju 2018 roku internetową metodą ankietową. Badaniami objęto polskich studentów, próba losowa wyniosła 327 osób. Wkład literatury pokrywają dane empiryczne i dowodzą, iż na prozdrowotny styl życia mają wpływ takie czynniki, jak: prawidłowe odżywianie, aktywność fizyczna, odporność na stres, unikanie używek oraz odpowiednia ilość snu. Wymienione postawy i zachowania studentów są istotne dla zdrowia. Artykuł jest znaczący w literaturze.
\end{abstract}

\section{Pro-health lifestyle of Polish students}

Abstract: The aim of the article is an identification of factors that determine the health of Polish university students. The article is based on a literature review and quantitative research carried out in April and May 2018 using the online questionnaire method. Polish students were examined, the random sample was 327 people. The knowledge from literature was confirmed by empirical data which proves that the pro-health lifestyle is influenced by such factors as: proper nutrition, physical activity, resistance to stress, avoidance of stimulants and adequate sleep. These student attitudes and behaviors are important for health. The article is a significant contribution to literature.

\section{Wprowadzenie}

Stan naszego zdrowia to bardzo często wynik stylu życia, jaki prowadzimy. Obecnie wiele chorób cywilizacyjnych jest spowodowanych złymi nawykami zdrowotnymi. Wśród nich wyróżniamy niezbilansowaną dietę ubogą w składniki

* Opiekun naukowy (Scientific Tutor) — prof. dr hab. Katarzyna Szalonka 
odżywcze, brak regularnej wolnoczasowej aktywności fizycznej o minimum średniej intensywności i w odpowiednim czasie, niedostateczną ilość snu, nadmierne stosowanie używek czy też nieradzenie sobie ze stresem ${ }^{1}$. Wszystkie wymienione zachowania natychmiastowo lub w przyszłości negatywnie odbiją się na naszym zdrowiu. Dlatego prozdrowotny styl życia jest niezwykle istotny w szczególności u młodych osób, ponieważ pozwala minimalizować ryzyko zachorowań w przyszłości oraz inne zachowania zagrażające życiu ${ }^{2}$. Dbanie o zdrowie młodego człowieka pozwala na wykorzystanie potencjału rozwojowego w zakresie psychicznym, duchowym, somatycznym i społecznym ${ }^{3}$. Jest to ważne zarówno dla osoby wkraczającej w dorosłe życie, jak i dla przyszłych pokoleń. Warto pamiętać, że troska o swoje zdrowie powinna być regularna i dostosowana do etapu życia. Taki tryb powinien zapewnić optymalne zdrowie, wysoką sprawność intelektualną i fizyczną oraz dłuższe życie. Celem artykułu jest wskazanie prozdrowotnych postaw i zachowań determinujących zdrowy styl życia wśród polskich studentów oraz przedstawienie wyników badań dotyczących tych czynników.

\section{Styl życia a zdrowie}

Literatura przedmiotu definiuje styl życia niejednoznacznie. Jest to termin socjologiczny o wielu znaczeniach. Woynarowska napisała, że styl życia to pewien złożony konstrukt dotyczący grupy społecznej i jednostki. W jego skład wchodzą różnie zdeterminowane czynniki, takie jak wzorce zachowań czy też analiza sytuacji występujących w konkretnej grupie społecznej ${ }^{4}$. Natomiast według Zofii Kawczyńskiej-Butrym stylem życia są codzienne wybory dotyczące sposobu odżywiania, stosowania używek i leków, podejścia do pracy i odpoczynku oraz aktywności fizycznej ${ }^{5}$. Nancy Milio charakteryzuje styl życia jako „wzory wyborów zachowań spośród alternatywnych możliwości, jakie dostępne są ludziom w zależności od ich sytuacji społeczno-ekonomicznej i łatwości, z jaką są w stanie przedłożyć określone zachowania nad inne"6. Zatem bezpośrednim czynnikiem, który oddziałuje na stan zdrowia, jest właśnie styl życia. Inną determinantą zdro-

1 T. Wyszyńska, Rozpoznawanie i leczenie nadciśnienia tętniczego u dzieci i młodzieży. Aktualne (2004) stanowisko amerykańskich ekspertów, Warszawa 2005, s. 13-27.

2 A. Ostrowska, Styl życia a zdrowie. Z zagadnień promocji zdrowia, Warszawa 1999, s. 13-14.

3 J. Cieślikowska, Szkolne zadania z zakresu promocji zdrowia a ogólno-pedagogiczne kompetencje nauczycieli do ich podejmowania, [w:] Środowisko, młodzież, zdrowie. Pedagogiczne i psychologiczne wymiary zagrożeń życia i rozwoju młodzieży, red. J. Malinowski, A. Zandecki, Torun 2007, s. 207-212.

${ }^{4}$ B. Woynarowska, Czynniki warunkujace zdrowie i dbałość o zdrowie, [w:] Edukacja zdrowotna, red. B. Woynarowska, Warszawa 2008, s. 44-74.

5 Z. Kawczyńska-Butrym, Wprowadzenie do diagnozy, [w:] Diagnoza pielęgniarska, red. Z. Kawczyńska-Butrym, Warszawa 1999, s. 11-43.

6 J. Ślusarski, Samoświadomość dorastajacej młodzieży w zakresie zdrowego stylu życia i sposobu odżywiania, Warszawa 2002, s. 188-191. 
wia, są uwarunkowania społeczno-ekonomiczne, a szczególnym zagrożeniem ubóstwo ${ }^{7}$. Warto dodać, że styl życia to również „ogół zachowań werbalnych i niewerbalnych niosących informacje o przynależności do konkretnej grupy społecznej"8. Obecnie obserwuje się wzrost świadomości z zakresu zdrowia oraz zainteresowania zdrowym trybem życia, które skutkują bardziej racjonalnym odżywianiem. Wybór danego trybu życia zależy od aspektów środowiskowych oraz cech emocjonalno-poznawczych ${ }^{9}$.

\section{Zachowania prozdrowotne}

Zachowania prozdrowotne odnoszą się do zachowań związanych z dziedziną zdrowia, które wywołują pozytywne skutki w naszym organizmie. Zachowania te od wczesnych lat młodości kształtują rodzice, szkoła i media. Wyróżniamy między innymi dbałość o ciało, sen, nawadnianie organizmu, zbilansowaną dietę, wysiłek fizyczny oraz radzenie sobie ze stresem ${ }^{10}$. Zachowania te wyznaczone są poprzez podłoże kulturowe i społeczne, co powoduje ograniczenie własnych wyborów. Zatem każde działanie, które ma podwyższać potencjał zdrowia lub jego utrwalenie, jest zaliczane do zachowań zdrowotnych.

Właściwe odżywianie jest niezwykle istotne i niesie wiele korzyści. Zbilansowana dieta dostarcza wszystkich niezbędnych składników odżywczych, witamin, makro- i mikroelementów kluczowych w prawidłowym funkcjonowaniu organi$\mathrm{zmu}^{11}$. Wartość odżywczą produktów definiuje się jako ich przydatność w zaspokajaniu potrzeb organizmu i procesów metabolicznych ${ }^{12}$. Antyoksydanty zawarte w owocach i warzywach hamują procesy oksydacyjne w organizmie, co ogranicza ryzyko zachorowań na przykład na miażdżycę ${ }^{13}$. Dzięki zbilansowanej diecie możemy zmniejszyć ryzyko wielu chorób: otyłości, cukrzycy typu 2, nadciśnienia, krzywicy, szkorbutu, kurzej ślepoty, osteoporozy. Spożywanie nadmiaru cukru prowadzi również do próchnicy zębów ${ }^{14}$. Obecnie istnieje wiele diet i wskazówek, w jaki sposób przygotować zdrowy posiłek. Najważniejsze jest, by opierając się na

7 M. Synowiec-Piłat, Promocja zdrowia i profilaktyka onkologiczna w działaniach organizacji pozarzadowych, Toruń 2009, s. 34.

8 Promocja zdrowia: wprowadzenie do zagadnień krzewienia zdrowia, red. J. Karski, Z. Słońska, B.W. Wasilewski, Warszawa 1994, s. 11-55.

9 D. Ponczek, I. Olszowy, Styl życia młodzieży i jego wplyw na zdrowie, ,Problemy Higieniczno-Epidemiologiczne" 93, 2012, s. 260-268.

10 B. Woynarowska, op. cit., s. 44-74.

11 M. Ogryzko-Wiewiórska, Zmiana przez zdrowie: promocja zdrowia dla grup szczególnego ryzyka, Lublin 2008, s. 32-71.

12 H. Gertig, J. Gawęcki, Słownik terminów żywieniowych, Warszawa 2001, s. 13-29.

13 M. Jarosz, B. Bułhak-Jachymczyk, Normy żywienia człowieka. Podstawy prewencji otyłości i chorób zakaźnych, Warszawa 2008, s. 359.

14 F.M. Biro, M. Wien, Childhood obesity and adult morbidities, „The American Journal of Clinical Nutrition” 2010, nr 91(5), s. 1499-1505. 
piramidzie żywienia, spożywać regularnie pięć małych posiłków dziennie, pamiętając, by do każdego dodawać owoce i warzywa ${ }^{15}$. Istotne jest także sprawdzanie składów kupowanych produktów oraz zaopatrywanie się w świeżą i ekologiczną żywność produkowaną naturalnymi metodami bez użycia pestycydów i nawozów sztucznych. Zainteresowanie się ekologicznymi lub „bio” produktami jest związane z dbałością o zdrowie, ekologię czy przekonaniami i etyką ${ }^{16}$. Warto pamiętać o nawadnianiu organizmu - optymalnie powinno się pić minimum półtora litra wody dziennie.

Kolejnym ważnym aspektem jest regularna aktywność fizyczna. Przyczynia się ona nie tylko do lepszej sprawności fizycznej czy ograniczenia ryzyka schorzeń somatycznych, lecz także do szczuplejszej sylwetki i dotlenienia mózgu. Dodatkowo ma pozytywny wpływ na psychikę, działa odstresowująco i poprawia samopoczucie ${ }^{17}$.

Odpowiednia ilość snu ma istotne znaczenie w prawidłowym funkcjonowaniu organizmu, ponieważ zapewnia odpoczynek. Komórki mózgowia mogą się zregenerować, co skutkuje lepszą koncentracją. Ilość snu jest regulowana indywidualnie przez organizm w zależności od wieku, wykonywanej pracy i innych czynników. Sen dorosłej osoby powinien trwać od sześciu do ośmiu godzin na dobę. Niedobór lub brak snu utrudnia wykonywanie wielu czynności, powoduje znużenie i brak energii ${ }^{18}$.

Prozdrowotny styl życia to również ograniczenie wszelkich używek, a najlepiej całkowity ich brak. Używka definiowana jest jako substancja niemająca składników odżywczych lub zawierająca śladowe ich ilości bez wpływu na organizm ${ }^{19}$. Do najczęściej spożywanych, a zarazem najniebezpieczniejszych zaliczamy tytoń, alkohol i narkotyki. Powodują wiele negatywnych konsekwencji, takich jak zaburzenia funkcjonowania różnych narządów, choroby oraz uzależnienie. Pozostałe, a zarazem najczęściej spożywane, to kawa i herbata, które nadmiernie konsumowane również mogą powodować negatywne skutki dla naszego organizmu.

Ostatnim czynnikiem wpływającym na zdrowy styl życia jest umiejętność radzenia sobie ze stresem. Długotrwały stres jest niszczący dla organizmu, może

15 E. Stecińska-Majkowska, Higiena, [w:] Czas wolny, rekreacja i zdrowie, red. W. Kuś, Warszawa 1981, s. 41-44.

16 J. Zrałek, Czynniki motywujące konsumentów do zakupu ekologicznej żywności - wyniki badań bezpośrednich, „Zeszyty Naukowe Uniwersytetu Szczecińskiego. Problemy Zarządzania, Finansów i Marketingu" 2010, nr 16, s. 391-400.

17 E. Stecińska-Majkowska, op. cit., s. 41-44.

18 A. Rogowska, B. Wojciechowska-Maszkowska, S. Adamska, Osobowość a styl życia osób zróżnicowanych pod względem aktywności fizycznej, Opole 2006, s. 108.

19 S. Berger et al., Żywienie człowieka, t. 1. Podstawy nauki o żywieniu, red. J. Gawęcki, Warszawa 2010, s. 18. 
powodować problemy psychiczne, brak snu i nerwicę, dlatego ważne jest, by go ograniczać ${ }^{20}$.

\section{Metodyka prowadzonych badań}

Badania przeprowadzono na 327 polskich studentach, w tym 251 kobietach i 76 mężczyznach, za pomocą ankiety internetowej. W tym celu wykorzystano kwestionariusz publikowany na portalach społecznościowych, zawierający siedemnaście pytań zamkniętych i półotwartych na temat zdrowego stylu życia. Badana próba jest reprezentatywna kwotowo względem wieku i statusu studenta. Zastosowano dobór celowy. Badania zostały przeprowadzone w kwietniu i maju 2018 roku. Dodatkowo do identyfikacji czynników prozdrowotnych służyła metryczka składająca się z sześciu pytań. Na jej podstawie można stwierdzić, że respondentami są głównie osoby studiujące stacjonarnie i niestacjonarnie w województwach: dolnośląskim (30\%), śląskim (13\%), opolskim (10\%), podkarpackim (10\%), wielkopolskim (8\%), lubuskim (6\%) i łódzkim (5\%). Wiek ankietowanych przestawia wykres 1 .

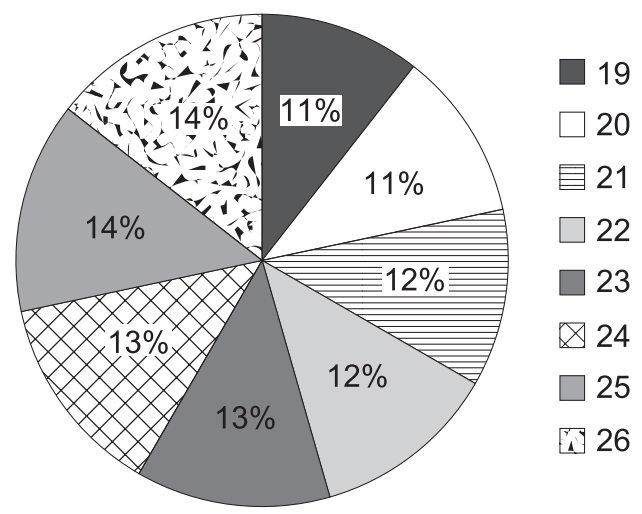

Wykres 1. Wiek respondentów

Źródło: opracowanie własne na podstawie badań własnych.

Większość studentów (57\%) pochodzi ze wsi lub małych miast do 50 tys. mieszkańców. Gospodarstwo domowe ankietowanych składa się średnio z czterech osób.

\section{Wyniki badań}

Analiza wyników badań przeprowadzonych wśród polskich studentów obrazuje zachowania zdrowotne determinujące prozdrowotny styl życia. Pierwszym

20 A. Rogowska, B. Wojciechowska-Maszkowska, S. Adamska, op. cit., s. 108. 
badanym czynnikiem było odżywianie. Regularność spożywania posiłków wśród studentów jest zróżnicowana. Najwięcej ankietowanych - 34\% — twierdzi, że spożywa cztery posiłki dziennie. Około jedna czwarta spożywa trzy posiłki. Jedynie $22 \%$ studentów odżywia się prawidłowo, jedząc pięć posiłków dziennie. Studenci mają świadomość, jak ważne jest spożywanie śniadania - $84 \%$ badanych zadeklarowało regularne spożywanie śniadań.

Kolejna kwestia dotyczyła spożywania pięciu porcji warzyw i owoców dziennie. Tutaj jednak wyniki są zaskakujące. Prawie $60 \%$ ankietowanych spożywa ich znacznie mniej. Prawidłowo odżywia się jedynie $20 \%$ studentów. Przedstawia to wykres 2.

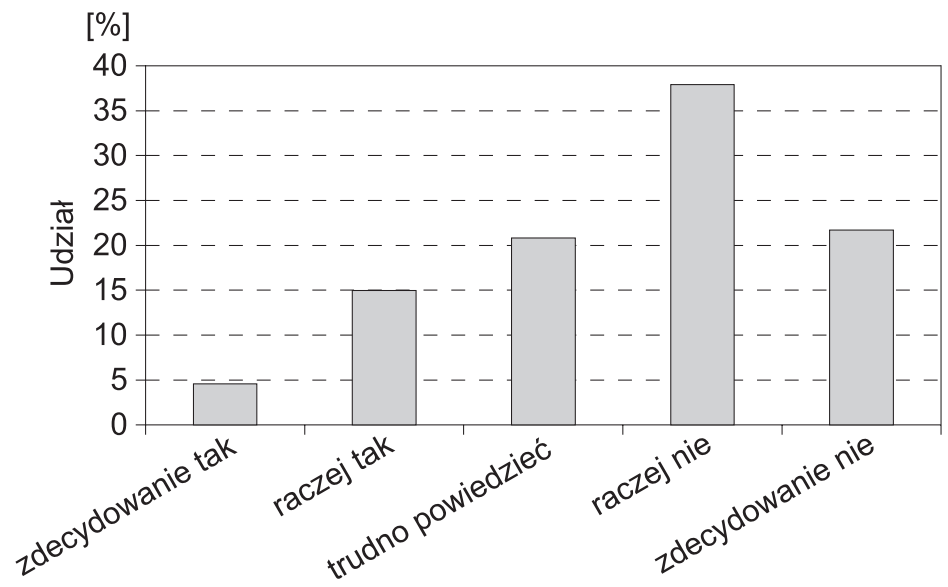

Odpowiedź

Wykres 2. Częstość spożywania pięciu porcji warzyw i owoców

Źródło: opracowanie własne na podstawie badań własnych.

Kolejny aspekt stanowi nawadnianie organizmu poprzez picie odpowiedniej ilości wody. Z ankiety wynika, że 59\% studentów wypija przynajmniej półtora litra wody dziennie. Zbilansowana dieta oparta na piramidzie żywieniowej jest podstawą zdrowego trybu życia. Najczęściej spożywanymi grupami produktów są: produkty zbożowe (65\%), owoce i warzywa (59\%) oraz nabiał (57\%). Fast foody i słodycze są jednocześnie spożywane przez 34\% studentów. Zdecydowana większość ankietowanych (dwie trzecie respondentów) nie kupuje ekologicznej żywności, jedynie 3\% przyznaje się do jej zakupu. Reszta studentów nie ma zdania na ten temat. Młodzi ludzie nie wiedzą również, dlaczego powinno się spożywać pięć porcji warzyw i owoców dziennie. Niektórzy uważają, że są zdrowe i mają dużo witamin, jednak nie jest to poprawna odpowiedź. Powodem jest krótka przyswajalność składników odżywczych z owoców i warzyw. Respondentów zapytano też, czy czytają składy produktów. Okazuje się, iż większość studentów 
(64\%) sprawdza składy przy zakupach. Badania dowodzą, że przekąski w formie słodyczy lub innych niezdrowych produktów spożywa aż 80\% młodzieży. Kanapka, sałatka lub owoc również stanowi częstą przekąskę zadeklarowaną przez około jedną trzecią studentów. Niezwykle ważnym determinantem prozdrowotnego stylu życia jest regularna aktywność fizyczna, czyli minimum trzy razy w tygodniu, o co najmniej średniej intensywności i trwająca minimum godzinę. Wśród najpopularniejszych form aktywności wyróżnia się: ćwiczenia na siłowni, fitness, bieganie, jazdę na rowerze. Dane empiryczne wskazują, że $40 \%$ studentów regularnie uprawia przynajmniej jeden sport. $17 \%$ badanych w ogóle nie poświęca czasu na aktywność fizyczną, twierdząc, iż nie ma na nią czasu. Pozostali ankietowani uprawiają sport sporadycznie jeden, dwa razy w tygodniu.

Analizie poddano również stosowanie wszelkich używek: $77 \%$ respondentów deklaruje spożywanie kawy i herbaty, 53\% — alkoholu oraz 13\% — papierosów. Prawie $80 \%$ ankietowanych przyznaje się do stosowania ich przynajmniej raz w tygodniu, z nich ponad 2/3 codziennie. Jedynie $12 \%$ respondentów w ogóle nie stosuje używek. Zapytano studentów o stopień zainteresowania zdrowym trybem życia. Wykres 3 pokazuje, że około $57 \%$ ankietowanych wykazuje zainteresowanie tym tematem.

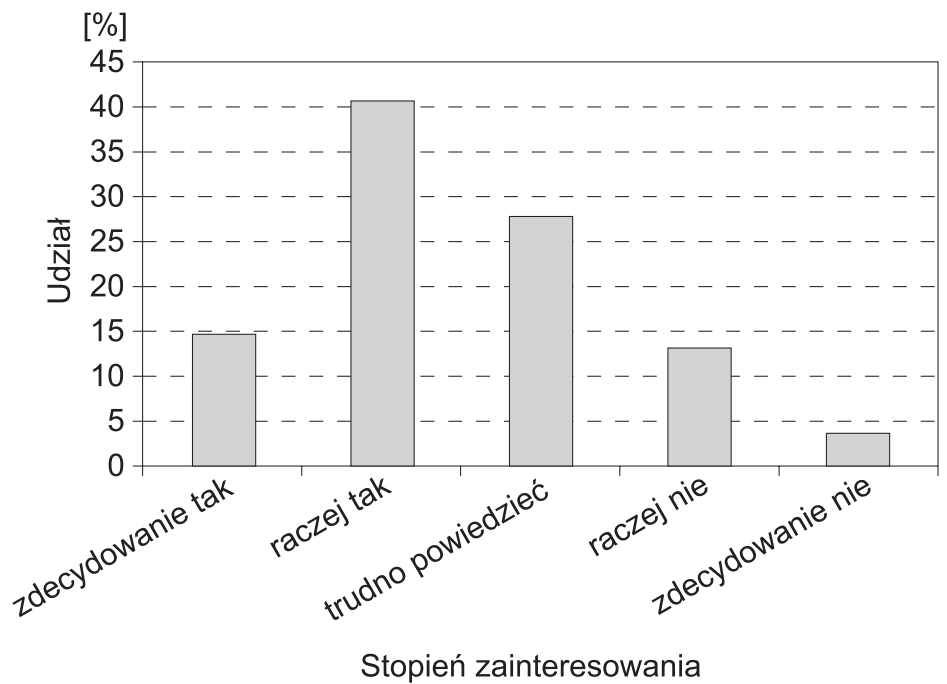

Wykres 3. Zainteresowanie studentów zdrowym stylem życia

Źródło: opracowanie własne na podstawie badań własnych.

Kolejne pytanie dotyczyło stanu zdrowia respondentów. 74\% ankietowanych dobrze lub bardzo dobrze ocenia swój stan zdrowia, jedynie 5\% ocenia go źle. Jak już podkreślono, odporność na stres i radzenie sobie z nim istotnie wpływa na stan zdrowia. Analiza badań dowodzi, że 53\% studentów nie radzi sobie ze stresem. 
Ostatnim badanym prozdrowotnym determinantem jest odpowiednia długość snu. Zalecane jest spanie przez minimum sześć, a najlepiej siedem godzin na dobę. Wyniki badań wskazują, iż prawie trzy czwarte studentów prawidłowo się wysypia.

Następną kwestią było badanie współczynnika należnej masy ciała BMI na podstawie masy ciała i wzrostu wśród studentów ${ }^{21}$. Wykres 4 pokazuje kształtowanie BMI.

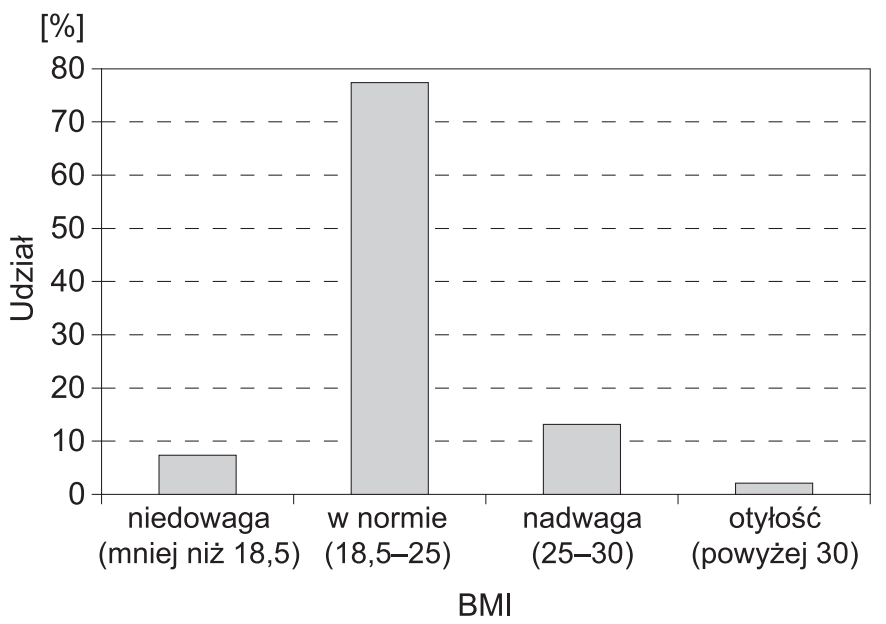

Wykres 4. Wskaźnik BMI studentów

Źródło: opracowanie własne na podstawie badań własnych.

Zestawienie odpowiedzi kobiet i mężczyzn jest niezwykle ciekawe. Wyniki wskazują, iż zdecydowanie więcej (30\%) mężczyzn nie spożywa śniadań w porównaniu do kobiet $(9 \%)$. Wartość testu chi-kwadrat(2) $=375,628 \mathrm{z}$ wartością $\mathrm{p}=2,71338 \mathrm{e}-082$ przy założeniu $\alpha=0$ udowadnia zależność badanej cechy. Regularną aktywność fizyczną praktykuje zatem $41 \%$ kobiet i 37\% mężczyzn. Warto dodać, iż odsetek kobiet nieuprawiających sportu jest ponad dwa razy wyższy niż mężczyzn - dla kobiet jest to $20 \%$, a dla mężczyzn $8 \%$. Test chi-kwadrat(2) $=44,036 \mathrm{z}$ wartością $\mathrm{p}=0,00(\alpha=0,05)$ oznacza, że związek jest istotny statystycznie. Badania dowodzą również istotną korelację pomiędzy brakiem aktywności fizycznej a wysokim wskaźnikiem BMI oznaczającym nadwagę (corr $=0,8)$. Kolejną kwestią różniącą obie płcie jest nieumiejętność radzenia sobie ze stresem, do czego przyznaje się aż 30\% kobiet i tylko $12 \%$ mężczyzn. Statystyka testu chi-kwadrat(2) tych zmiennych $=716,187 \mathrm{z}$ wartością $\mathrm{p}=3,03407 \mathrm{e}-156(\alpha=0,05)$ potwierdza istotność zależności. Problem zbilansowanej diety dotyczy w równej mierze kobiet i mężczyzn. Dwie trzecie ankietowanych spożywa w ciągu dnia

${ }^{21}$ M. Bernas, Kliniczna definicja i ocena otyłości, „Terapia” 2005, nr 5 (166), s. 7-9. 
słodycze, chipsy lub fast foody. Studenci często korzystają z takich używek, jak kawa, herbata, alkohol, tytoń. Wykres 5 prezentuje różnice między kobietami a mężczyznami w spożywaniu używek.

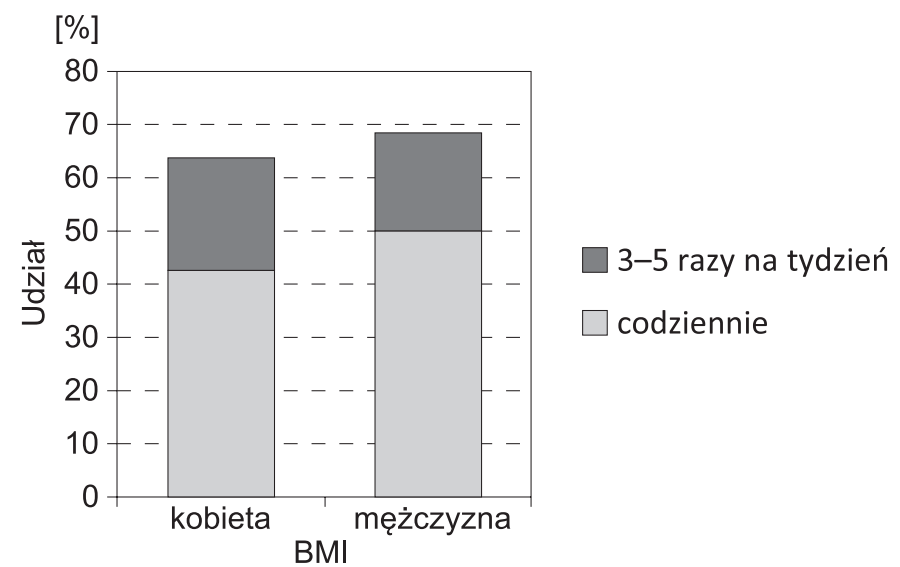

Wykres 5. Częstość spożywania używek wśród studentów

Źródło: opracowanie własne na podstawie badań własnych.

Analiza danych wskazuje, że spożywanie pięciu porcji warzyw i owoców oraz jednoczesne picie minimum półtora litra wody dziennie deklaruje tylko 15\% osób. Co ważne, jedynie 4\% ankietowanych regularnie je śniadania i spożywa pięć posiłków dziennie. Studenci, którzy jedzą pięć porcji warzyw i owoców, kupują ekologiczną żywność i piją minimum półtora litra wody, stanowią niecałe $15 \%$ ankietowanych.

\section{Podsumowanie}

Reasumując, należy jeszcze raz podkreślić, że na prozdrowotny styl życia składa się wiele elementów. Zgromadzony materiał umożliwił wysnucie następujących wniosków: większość polskich studentów stara się prawidłowo odżywiać, ponad połowa spożywa minimum cztery posiłki dziennie, natomiast $84 \%$ regularnie je śniadanie, z czego większy odsetek to kobiety. Badania dowodzą, że jedynie $20 \%$ ankietowanych spożywa odpowiednią ilość owoców i warzyw, co oznacza, że polska młodzież może mieć niedobory witamin i innych składników odżywczych. Młodzi ludzie przeważnie nie kupują ekologicznej żywności, jednak czytają składy produktów. Około $80 \%$ studentów spożywa w ciągu dnia niezdrowe przekąski i tyle samo stosuje używki. Badania dowodzą również, że prawie jedna trzecia kobiet nie radzi sobie ze stresem, podczas gdy u mężczyzn jest to tylko $12 \%$. Zdecydowana większość ankietowanych śpi minimum siedem godzin na dobę. Duża część (40\%) polskich studentów regularnie uprawia sport. Analizując 
wymienione czynniki, można dojść do wniosku, że ogólna dbałość o zdrowie wśród studentów jest wyższa niż się spodziewano. Wyniki BMI wskazują, iż 74\% respondentów ma prawidłową masę ciała.

\section{Bibliografia}

Berger S. et al., Żywienie człowieka, t. 1. Podstawy nauki o żywieniu, red. J. Gawęcki, Warszawa 2010.

Bernas M. Kliniczna definicja i ocena otyłości. Terapia 2005; 5 (166): 7-9.

Biro F.M., Wien M., Childhood obesity and adult morbidities, „The American Journal of Clinical Nutrition" 2010, nr 91(5).

Cieślikowska J., Szkolne zadania z zakresu promocji zdrowia a ogólno-pedagogiczne kompetencje nauczycieli do ich podejmowania, [w:] Środowisko, młodzież, zdrowie. Pedagogiczne i psychologiczne wymiary zagrożeń życia i rozwoju młodzieży, red. J. Malinowski, A. Zandecki, Torun 2007.

Gertig H., Gawęcki J., Stownik terminów żywieniowych, Warszawa 2001.

Gniazdowski A. et al., Zachowania zdrowotne. Zagadnienia teoretyczne, próba charakterystyki zachowań zdrowotnych społeczeństwa polskiego, red. A. Gniazdowski, Łódź 1990, s. 83.

Jarosz M., Bułhak-Jachymczyk B., Normy żywienia człowieka. Podstawy prewencji otyłości i chorób zakaźnych, Warszawa 2008.

Kawczyńska-Butrym Z., Wprowadzenie do diagnozy, [w:] Diagnoza pielęgniarska, red. Z. Kawczyńska-Butrym, Warszawa 1999.

Ogryzko-Wiewiórska M., Zmiana przez zdrowie: promocja zdrowia dla grup szczególnego ryzyka, Uniwersytet Marii Curie-Skłodowskiej, Lublin 2008, s. 32-71.

Ostrowska A., Styl życia a zdrowie. Z zagadnień promocji zdrowia, Warszawa 1999.

Promocja zdrowia: wprowadzenie do zagadnień krzewienia zdrowia, red. J. Karski, Z. Słońska, B.W. Wasilewski, Warszawa 1994.

Ponczek D., Olszowy I., Styl życia młodzieży i jego wpływ na zdrowie, „Problemy Higieniczno-Epidemiologiczne" 93, 2012.

Rogowska A., Wojciechowska-Maszkowska B., Adamska S., Osobowość a styl życia osób zróżnicowanych pod względem aktywności fizycznej, Opole 2006.

Stecińska-Majkowska E., Higiena, [w:] Czas wolny, rekreacja i zdrowie, red. W. Kuś, Warszawa 1981.

Synowiec-Piłat M., Promocja zdrowia i profilaktyka onkologiczna $w$ działaniach organizacji pozarządowych, Toruń 2009.

Ślusarski J., Samoświadomość dorastającej młodzieży w zakresie zdrowego stylu życia i sposobu odżywiania, Warszawa 2002.

Woynarowska B., Czynniki warunkujace zdrowie i dbałość o zdrowie, [w:] Edukacja zdrowotna, red. B. Woynarowska, Warszawa 2008.

Wyszyńska T., Rozpoznawanie i leczenie nadciśnienia tętniczego u dzieci i młodzieży. Aktualne (2004) stanowisko amerykańskich ekspertów, Warszawa 2005.

Zrałek J., Czynniki motywujące konsumentów do zakupu ekologicznej żywności - wyniki badań bezpośrednich, ,Zeszyty Naukowe Uniwersytetu Szczecińskiego. Problemy Zarządzania, Finansów i Marketingu" 2010, nr 16. 


\section{Pro-health lifestyle of Polish students}

\section{Summary}

To sum up, many factors determine the pro-health lifestyle. The collected material made it possible to draw conclusions: most Polish students try to eat properly, more than half consume a minimum of four meals a day, while $84 \%$ regularly eat breakfast, of which a large proportion are women. Research shows that only $20 \%$ of respondents consume the right amount of fruit and vegetables, which means that Polish youth may have deficiencies of vitamins and other nutrients. Mostly young people do not buy organic food, but they do check the product ingredients. About $80 \%$ of students eat unhealthy snacks during the day and $80 \%$ take substances. Research also shows that almost one third of women does not deal with stress, while for men it is $12 \%$. The vast majority of respondents sleeps at least 7 hours a day. A large part (40\%) of Polish students regularly plays sports. Analyzing the aforementioned factors, we can conclude that general health care among students is above average, which is confirmed by good BMI results indicating that $74 \%$ of respondents have normal body mass. 